\title{
Kézírásfelismerés Arany János levelein
}

\author{
Bobák Barbara \\ Magyar Tudományos Akadémia Bölcsészettudományi Kutatóközpont \\ Irodalomtudományi Intézet \\ bobak.barbara@btk.mta.hu \\ Gábori Kovács József ${ }^{1}$ \\ Magyar Tudományos Akadémia Bölcsészettudományi Kutatóközpont \\ Irodalomtudományi Intézet \\ kovacs.jozsef@btk.mta.hu
}

\begin{abstract}
Arany János 1865-1869 között titoknoki, majd 1870-1877 között fötitkári minöségben segítette az MTA munkáját. Az író tehát csaknem másfél évtizeden keresztül látott el fontos tudományszervezési feladatokat. ${ }^{2}$ Életmüvének kutatása ezért elképzelhetetlen hivatali iratainak, levelezésének feltárása és publikálása nélkül. E dokumentumok vizsgálata kiegészitheti olvasmányainak listáját, tisztázhatja, hogy milyen mértékben vett részt az Akadémia kiadványainak elkészitésében, valamint segitséget nyújthat annak felismerésében, hogy a hivatali foglalatosság milyen, eddig nem ismert kapcsolatokat teremthetett az ö költészetével. Továbbá ezek a dokumentumok kulcsszerepet játszhatnak az Akadémia szervezeti rendszerének leirásában, az 1870-es átszervezés okainak, az Akadémia hazai és külföldi intézményes kapcsolatainak feltárásában; reprezentációs szerepének, illetve tudományszervezésben elfoglalt pozíciójának meghatározásában. Az intézmény sokfelé ágazó tudományszervezési feladatait alapvetően meghatározta az a tény, hogy az Akadémia számos tudományterület képviselőit - nyelvés széptudományok, bölcseleti tudományok, törvénytudományok, történeti tudományok, matematikai tudományok és természettudományok - fogta össze a korszakban. E tudományterületek külső - hazai és külföldi - intézményekkel és kutatókkal való kapcsolattartása pedig rendszerint a mindenkori titoknok, illetve az általa vezetett Titoknoki, később Fötitkári Hivatal közvetitésével történt, így Arany János hivatali levelezésének kiadása az emlitett tudományterületek és a hozzájuk a korszakban sorolt tudományágak történetének, fejlödésének, hazai és külhoni intézmény- és kapcsolatrendszerének vizsgálatához is nélkülözhetetlen adatokat nyújthat.
\end{abstract}

1 Gábori Kovács József a tanulmány irásának ideje alatt MTA Prémium Posztdoktori Ösztöndij támogatásban részesült.

2 Gergely Pál. „Bevezetés". In: Arany János. „Hivatali iratok 2:: Akadémiai évek (1859-77)”. szerk., jegyz. Gergely Pál. Bp. Akadémiai K. (1964) (Arany János összes müvei, 14.): 602-604. ; Arany akadémiai feladatairól lásd még Gergely Pál. „Arany János és az Akadémia." Bp. MTA Irodalomtudományi Intézete - Akadémiai K. (1957). (Irodalomtörténeti füzetek, 11.) ; Keresztury Dezső. „Csak hangköre más: Arany János 1857-1882." Bp. Szépirodalmi K. (1987): 468-480. Voinovich Géza. „Arany János életrajza 1860-1882.” Bp. Magyar Tudományos Akadémia (1938): 205-214. 
Korábban, az Arany János összes müvei címü kritikai kiadás XIV. kötetének összeállitása során Gergely Pál elkészitette Arany akadémiai iratainak jegyzékét. Ő körülbelül 2500 dokumentumot sorolt fel, ám ennek csak kisebb részét - 717 - tette közzé. ${ }^{3} \mathrm{Ez}$ a tény és a kötet megjelenése óta eltelt több mint ötven év eredményei szükségessé tették Gergely jegyzékének felülvizsgálatát és kiegészitését. Főként mivel a kötet összeállítása során a szerkesztő szinte csak az Arany által írott hivatali iratok közül válogatott, míg az Akadémia titoknokához irott levelek közül csak a legfontosabbak kerültek a gyüjteménybe. ${ }^{4}$

Mindezeket szem elött tartva vált indokolttá, hogy Arany János hivatali levelezésére essen a választás a gépi kézirásfelismerés és átírás tesztelésére, valamint fejlesztésére. A papíralapú dokumentumok digitalizálásának fontossága kétségbevonhatatlan. A tartós megörzés, az egyszerübb tárolhatóság, a könnyebb és sokrétübb feldolgozhatóság mind indokolja azt. Függetlenül attól, hogy a humán tudományok területén munkálkodó kutatók a mai napig print kiadásokat, továbbá kéziratokat használnak munkájukhoz, egyre több irásos anyag rendelkezik elektronikus verzióval is, az újonnan születő müvek jelentős hányada pedig már eleve digitális formában jön létre. A technika fejlődésével és térhóditásával tehát megváltozott a tudásanyag megszerzésének - és létrehozásának - a módja, megváltoztak az információhoz való hozzáférésre vonatkozó igények, ami szintén a digitalizálás elkerülhetetlensége felé mutat.

Egy szöveges dokumentum digitalizálásának legföbb lépései a szkennelés és a karakterfelismerés, legyen szó akár nyomtatott, akár kézzel irt szövegröl. Nyomtatott szövegek esetén az optikai karakterfelismerés (OCR), irott szövegek esetén pedig a kézirásfelismerés (HTR) technológiáját alkalmazzuk.

\section{Az OCR}

A digitalizálási folyamat első lépése a szkennelés, amikor a papíralapú dokumentumokról jó minőségü, magas pontsürüségü (min. 600 dpi5) szkennelt képek készülnek. Ezt követően a képeken valamilyen OCR program kerül futtatásra, amellyel további információt tudunk kinyerni a szkennelt anyagból. Az optikai karakterfelismerés (Optical Character Recognition - OCR) olyan technológia, amely felismerhetővétesziegyképenvagyszkenneltdokumentumonszereplőkaraktereket, számokat és központozási jeleket. A folyamatban nehézséget jelentenek azok a zajnak nevezett elemek, amelyek egy nyomtatott dokumentumban elöfordulhatnak, például egy folt vagy gyürödés a papíron, homályos háttér, tintafoltok stb. A karakterfelismerő teljesítményét tanulással lehet fejleszteni, így idővel képessé válik olyan karakterek és minták azonositására is, amelyekkel korábban nem találkozott. ${ }^{6}$

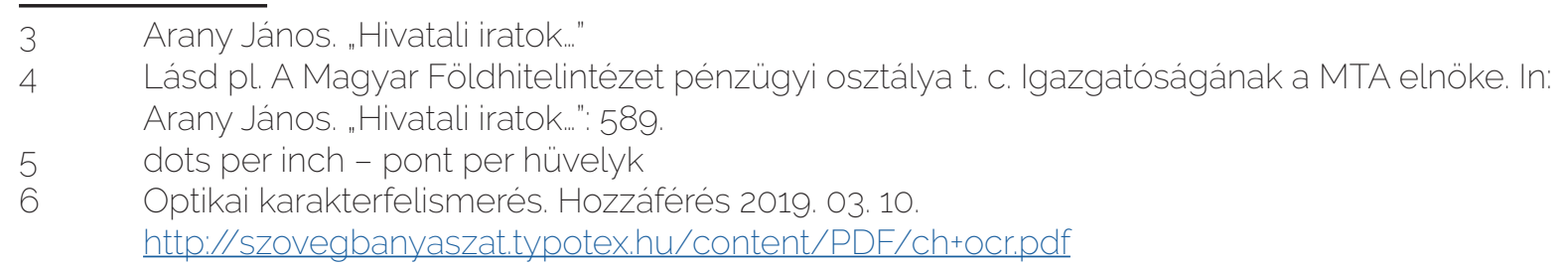




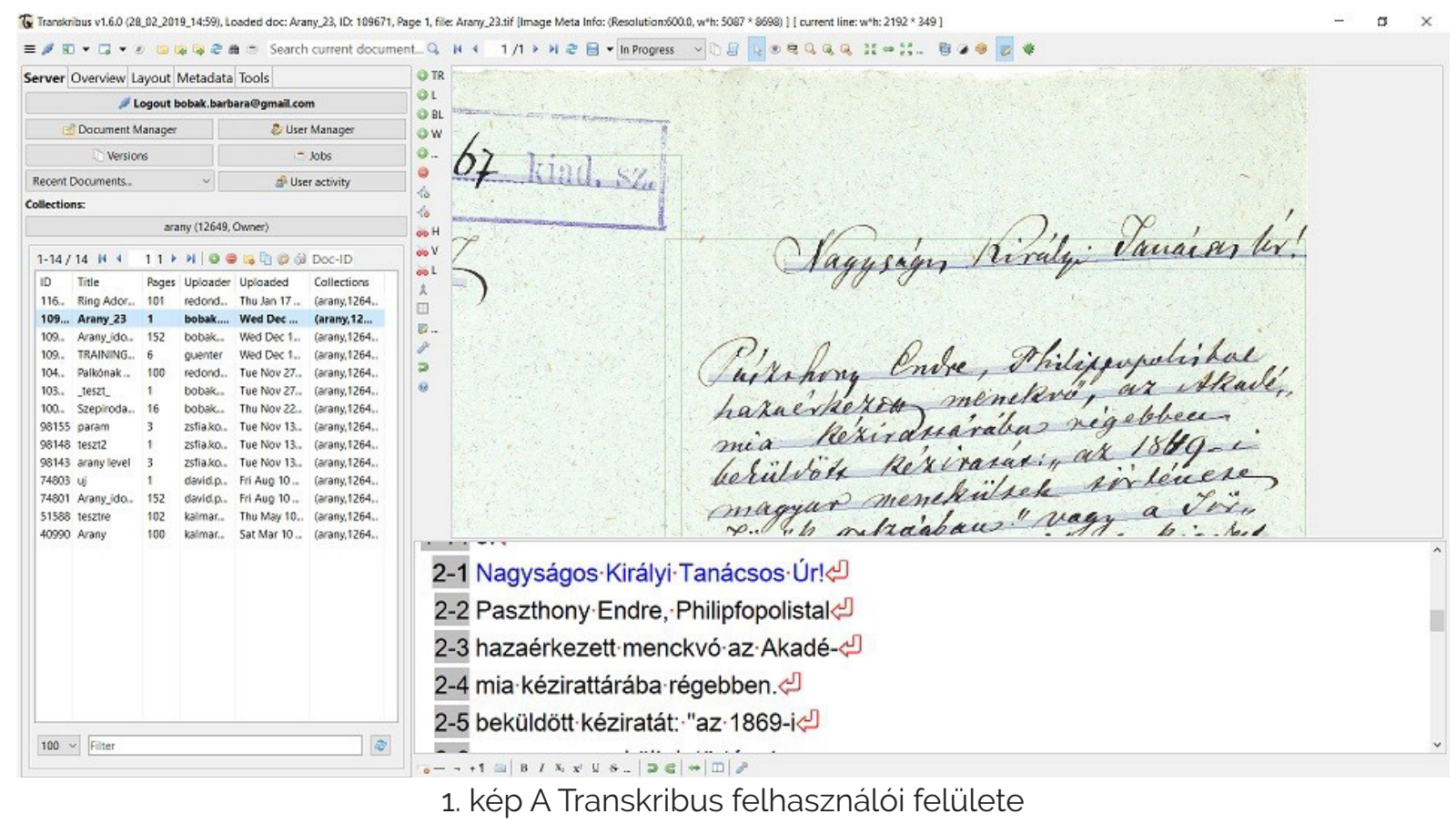

Az OCR alkalmazása által tehát a képekböl szövegfájl formátumok jönnek létre, amelyek szerkeszthetők és kereshetők, vagyis alkalmasak a feldolgozásra.

\section{A HTR}

Ha a digitalizálni kivánt dokumentum nem nyomtatott, hanem kézírásos, abban az esetben kézírásfelismerő (Handwritten Text Recognition - HTR) programra van szükség. A cél ugyanaz, mint a nyomtatott szövegek esetében, azaz a kéziratról készült szkennelt képfájlból feldolgozásra alkalmas szövegfájl formátum létrehozása. A folyamatot itt is nehezitik mindazok a zajelemek, amik a nyomtatott dokumentumokban is elöfordulhatnak, kézirásnál azonban a személyiségjegyekkel is számolni kell, hiszen ahány ember, annyiféle kézírás létezik. Az OCR technológiájához hasonlóan a HTR is tanulási fázison megy keresztül, ami alkalmassá teszi a szöveget alkotó karakterek felismerésére, késöbb pedig új minták azonositására is.

Az OCR és a HTR térhóditásával olyan számítógépes alkalmazások és online szolgáltatások is megjelentek, amelyek képesek mindkét technológiát alkalmazni a feltöltött dokumentumokon.

\section{Transkribus ${ }^{7}$}

A Transkribus online szolgáltatás, amellyel nyomtatott szövegek és kéziratok felismertetését és átírását végezhetjük, jelentős mennyiségü munkaórát megspórolva. 2016-ban az Innsbruck Egyetem Digitalizálás és Digitális Archiválás 
kutatócsoportja (DEA) ${ }^{8}$ hozta létre a READ ${ }^{9}$ projekt részeként, és azóta is folyamatosan fejlesztés alatt áll. A szolgáltatás, melynek jelentős része nyilt forráskódú, mindenki számára ingyenesen elérhető. A Transkribus, a szolgáltatás honlapjáról egy regisztrációt követően letölthető és telepithető, használatához azonban internetelérés szükséges.

Az alkalmazás felülete rendkivül felhasználóbarát, logikusan felépitett és tagolt, az egyes funkciók könnyen elérhetök. A kialakitásnál láthatóan fontos szempont volt, hogy azok is könnyen boldogulhassanak vele, akik a technológiára kevésbé fogékonyak. A könnyen kezelhetőség célkitüzését az is bizonyítja, hogy a szolgáltatás wiki oldalán számos, részletesen leirt és képekkel illusztrált .pdf, valamint videó formátumú használati útmutató tölthetö le angol és német nyelven. ${ }^{10}$

\begin{tabular}{|c|c|}
\hline Első modell & Második modell \\
\hline $\begin{array}{l}\text { f0 .lf-én - } \\
\text { re. oldy F. } \\
\text { ezennele } \\
\text { Tidlobb } \\
\text { zklá sz. } \\
\text { zoalaááédáéb } \\
\text { eMI. } \\
\text { MM865... } \\
186186 \mathrm{j} \text { éé aa } \\
\text { zos. m á a a } \\
\text { s } \\
\text { Nagysags Krályi Taneilcr } \\
\text { aszthoy Endre, Phdifyopolisbol } \\
\text { hazaészezett. menckvö, az Akadé- } \\
\text { mia kezrdttárába régebben. } \\
\text { beküldött keziratati, "az 1869-i } \\
\text { magyar menekültet törtenéte } \\
\text { Török országban vagy a For- } \\
\text { ténelmi Bizottsag últal kiadat- } \\
\text { m vagy, högy ö maga kiadhasa } \\
\text { mg } \\
\text { s ez autal sányorú helyzeten } \\
\text { valamit könyéthessem, el nmn- } \\
\text { fogadás esetere visszakerven. } \\
\text { a folyó hó 9-én tartott } \\
\text { ostályüles határozatából } \\
\text { szerencsém van. e dolyozatot } \\
\text { aztenni a mondott Bizott } \\
\text { sághozs véleményada } \\
\text { vegon .A menmngrvea jedig elö } \\
\text { re lavható volaa hogv e kez }\end{array}$ & $\begin{array}{l}5 . \\
7301867 \text { kiad. sz. } \\
720 \text { Toldy J. } \\
\text { ezennel } \\
\text { millobb } \\
\text { iejellilölböz } \\
\text { t i ibi. } \\
\text { 1é851771 } \\
\text { MMAÉL. } 7.1885 \\
\text { 136/1867 levélt. szám. } \\
\text { G } \\
\text { 99t175 d. rérééj8 tá. } \\
3 \\
\text { Nagyságos Királyi Tanácsos Úr! } \\
\text { aszthony Endre, Philipgopolisból } \\
\text { hazaérkezett, ménckvö, az Akadé- } \\
\text { mia kézirdttárába régebben } \\
\text { beküldött kéziratát: "az 1869-i } \\
\text { magyar menekültek története } \\
\text { Török országban" vagy a Tor- } \\
\text { ténelmi Bizottság által kiadat- } \\
\text { m vagy, hogy ő maga kiadhatsa } \\
\text { s ez által sanyára helyzeten } \\
\text { valamit könyethessen, el nem, } \\
\text { fogadás esetére visszak érvén; } \\
\text { a folyó hó 9-én tartott } \\
\text { osztályáles határozatábal } \\
\text { szerincsém vann e dolgozatat } \\
\text { áttenni a mondott Bizott- } \\
\text { sághozg véleményada } \\
\text { algosy A nenvren pedig elö }\end{array}$ \\
\hline
\end{tabular}

2. kép Az első és a második modellel felismertetett levélrészlet

\footnotetext{
8 Digitalisierung \& Elektronische Archivierung (DEA). Hozzáférés: 2019. 03. 10. https://www.uibk.ac.at/germanistik/einrichtungen/dea.html

9 Recognition and Enrichment of Archival Documents. Hozzáférés: 2019. 03. 10 https://read.transkribus.eu/about/

10 Transkribus - How to Guides. Hozzáférés: 2019. 03. 10.

https://transkribus.eu/wiki/index.php/How_to_Guides
} 
Az átírásra szánt dokumentumokat kollekciókba kell gyüjteni, az egyes kollekciók igy számos dokumentumot tartalmazhatnak, mennyiségükre nincs megkötés.

A Transkribus - lehetőségeiböl és funkcióiból adódóan - tartalmaz optikai karakterfelismerő és kézírásfelismerő modult is. Egy feltöltött dokumentum feldolgozásának első lépése a megfelelő szegmentálás, azaza képfájlon lévőszöveg sorainak a beazonosítása és kijelölése. Megadható, hogy a dokumentum egészén vagy csak bizonyos oldalain menjen végbe a szegmentálás. A végeredmény szabad

\begin{tabular}{|l|c|c|}
\hline & Token & Karakter \\
\hline Elsô modell & $128 / 200$ & $276 / 954$ \\
\hline & $64 \%$ & $29 \%$ \\
\hline
\end{tabular}

\begin{tabular}{|l|c|c|}
\hline Második modell & $48 / 200$ & $116 / 954$ \\
\hline & $24 \%$ & $12 \%$ \\
\hline
\end{tabular}

1. táblázat A modellek tesztelésének hibaszázalékai

kézzel javitható, vagy teljes egészében pótolható, amennyiben az automatikus azonositás nem ment végbe megfelelően. Következő lépésként a kijelölt szegmentumokon futtatható az OCR vagy HTR, a feltöltött dokumentum jellegétöl függően. Kézirásfelismerés esetén szükséges egy modell kiválasztása is, amely az adott nyelv karakterkészleti sajátosságainak felismerésére lett létrehozva, és ami tanitható további feltöltött és hibátlanul átírt dokumentumok révén, ezzel növelve a hatékonyságát. A Transkribus angol és német nyelvre tartalmaz beépitett modellt, azonban kérhető bármely más nyelvre is, amennyiben megfelelő mennyiségü (min. 15000 átírt szó) ${ }^{11}$ és minőségü átírt dokumentum áll rendelkezésére. Az átírt szöveg végül számos formátumban exportálható: kétrétegü PDF, TEI, DOCX, TXT, stb.

\section{A korpusz}

Arany János hivatali iratainak összegyüjtése és feldolgozása az Arany János munkái kritikai kiadáshoz kapcsolódva 2014 szeptemberében vette kezdetét. A munka során eddig hol két, hol egy munkatárs tevékenysége révén kb. 2000 dokumentum betühiv, nyers átirata készült el, nagyjából 2400 oldal terjedelemben, részben .docx formátumban, részben a LyX dokumentum előkészítő rendszer kritikai kiadás készitésére alkalmassá tett, Hegedüs Béla által fejlesztett verziójában. Eközben befejezödött a hivatali iratok túlnyomórészt az MTA Könyvtár és Információs Központ Kézirattárában található anyagának szkennelése is, amely kb. 9200 dokumentumról nagyjából 30000 felvételt eredményezett. A Transkribus teszteléséhez ebböl a jelentős mennyiségü anyagból került felhasználásra - ezen szöveg megírásáig 200 oldalnyi kézirat az Eötvös Loránd Tudományegyetem Bölcsészettudományi Kar Digitális Bölcsészet Központ kezdeményezésére és együttmüködésében.

11 Transkribus - Questions and Answers. Hozzáférés: 2019. 03. 10.

https://transkribus.eu/wiki/index.php/Questions_and_Answers 


\section{Tesztelés}

A teszteléshez két lépésben, 100-100 oldalnyi kézzel átírt - pontosabban a HTR eredményén javitott - levelet biztositottunk a szolgáltatás fejlesztőinek, a magyar nyelvre vonatkozó modell létrehozására és tanítására. Bár a Transkribus hivatalos leírása szerint már kb. 75 oldalnyi szöveg is elegendő lehet a tanulási fázishoz, a magyar nyelv esetében az első 100 oldalt követően csekély sikerrel tudott a modell boldogulni a kézírással. Teljesitménye összességében körülbelül 30\%-ra volt tehetö, ha nem vesszük figyelembe például a leveleken szereplö pecsétek szövegeit. Ezeket a modell szintén próbálta kiolvasni, gyakorlatilag eredménytelenül, amiben közrejátszott a pecsétek elhelyezkedése és árnyalata is.

A második körben biztositott további 100 oldalnyi átirattal azonban számottevően javult a modell teljesitménye. Nagyságrendileg csupán egy hibásan átírt szó fordult elő soronként. Fontos ugyanakkor megjegyezni, hogy mindegyikalkalommalazonos személytől származó kéziratok átirataival ment végbe a fejlesztés. A cél viszont az, hogy a modell képessé váljon bármilyen magyar nyelvű kézirás felismerésére a lehető legkisebb hibázási aránnyal. Ennélfogva a tesztelés következő szakaszában egy másik személytöl származó, de időben ugyanakkor keletkezett kéziratok átiratát szolgáltatjuk a tanulási fázishoz.

Az 1. táblázat a két modell teljesitménybeli különbségeit mutatja számszerü és százalékos formában is. Egy tetszőlegesen kiválasztott levélen le lett futtatva mindkét modell, a végeredményül kapott átiratokból pedig véletlenszerüen ki lett emelve ugyanaz a 200 db token ${ }^{12}$. A táblázatból kiolvasható, hogy a modellek mennyi hibát ejtettek a tokenek szintjén, valamint a tokeneken belül a karakterek szintjén. Mig az első modell a mintának több mint felét (64\%) elrontotta, a karaktereknek pedig majd harmadát (29\%) nem tudta felismerni, addig a második modellnél ezek a hibaértékek valamivel több mint felére csökkentek. Fontos azonban megjegyezni, hogy ezek az arányok nagyon kis méretü mintát jelképeznek, nagyobb méretü, vagy akár a teljes átiratok összehasonlítása ezeket az arányokat valamelyest módosithatják.

\section{Konklúzió}

Az eddig összegyüjtött 9200 hivatali irat kiadása, nyomtatott kötetenként 700 dokumentummal számolva, 13-14 kötetben valósulhatna meg, ami a kritikai kiadások elkészitésének szokásos idötartamával - 8-10 év - kalkulálva, minimum 104 munkaévet venne igénybe. Ezt az időt pedig lerövidithetné egy kéziratátíróprogram használata, még akkor is, ha a program által elkészitett nyers átiratok ellenörzése, a hivatalos átírási elveknek való megfeleltetése, valamint a kritikai és magyarázó jegyzetek elkészítése továbbra is a textológusok feladata lenne. A kézzel írt karaktereket tehát némi betanitás után nagy hatásfokkal felismerni képes programjelentős segitséget nyújthat a szövegkiadások elkészitésében, ám ez föként akkor lehet igaz, ha a szövegkiadó az eredeti írásképet leginkább megőrző betühü

12 Szóköztől szóközig tartó karaktersorozat 
átiratok készitésére törekszik, illetve, ha az átíró program felhasználói felületén a gép által készitett nyers átiraton a kivánt változtatások rögtön el is végezhetök, azaz az emlitett szövegszerkesztő alkalmas kritikai szöveg készitésére is.

Mindazonáltal a jelenleg - ingyenesen - elérhető online kézírásfelismerő és átíró szolgáltatásokközüla Transkribus bizonyula leghasznosabbnakaszövegfeldolgozás területén. Szabadon hozzáférhető, a lényeges eszközöket magába foglaló, nagyfokú teljesítményjavulásra képes szolgáltatás, amellyel még úgy is jelentős mennyiségü munkaórát tud megspórolni egy kutató, hogy az automatikus átírás végeredménye továbbra is ellenörzést igényel. Felhasználóbarát kialakitásának köszönhetően pedig egyedülálló a maga kategóriájában, szemben azokkal a szövegfeldolgozó alkalmazásokkal, amelyek informatikai és/vagy programozási háttértudást igényelnek a müködtetésükhöz, valamint grafikus felülettel sem rendelkeznek.

\section{Bibliográfia}

Arany János. „Hivatali iratok 2.: Akadémiai évek (1859-77)”. szerk., jegyz. Gergely Pál. Bp. Akadémiai K. (1964) (Arany János összes müvei, 14.)

Digitalisierung \& Elektronische Archivierung (DEA). Hozzáférés: 2019. 03. 10. https://www.uibk.ac.at/germanistik/einrichtungen/dea.html

Gergely Pál. „Arany János és az Akadémia.” Bp. MTA Irodalomtudományi Intézete Akadémiai K. (1957). (Irodalomtörténeti Füzetek, 11.)

Keresztury Dezső. „Csak hangköre más: Arany János 1857-1882.” Bp. Szépirodalmi K. (1987)

Optikai karakterfelismerés. Hozzáférés 2019. 03. 10.

http://szovegbanyaszat.typotex.hu/content/PDF/ch+ocr.pdf

Recognition and Enrichment of Archival Documents. Hozzáférés: 2019. 03. 10. https://read.transkribus.eu/about/

Transkribus. Hozzáférés: 2019. 03. 10. https://transkribus.eu/Transkribus/

Transkribus - How to Guides. Hozzáférés: 2019. 03. 10.

https://transkribus.eu/wiki/index.php/How_to_Guides

Transkribus - Questions and Answers. Hozzáférés: 2019. 03. 10.

https://transkribus.eu/wiki/index.php/Questions_and_Answers

Voinovich Géza. „Arany János életrajza 1860-1882.” Bp. Magyar Tudományos Akadémia (1938) 